\title{
THE Role OF Higher EdUCATION InSTITUTIONS: RECRUITMENT OF ELITES AND ECONOMIC GROWTH
}

\author{
ELISE S. BREZIS \\ FRANÇOIS CROUZET
}

\author{
CESIFO WORKING PAPER NO. 1360 \\ CAtegory 5: Fiscal Policy, Macroeconomics AND Growth
}

DECEMBER 2004

Presented at CESifo Venice SuMmer Institute,

WORKSHOP ON INSTITUTIONS AND GROWTH, JULY 2004

\footnotetext{
An electronic version of the paper may be downloaded

- from the SSRN website: Www.SSRN.com

- from the CESifo website: www.CESifo.de
} 


\title{
THE RoLE OF HigHER EDUCATION INSTITUTIONS: RECRUITMENT OF ELITES AND ECONOMIC GROWTH
}

\begin{abstract}
The aim of this paper is to examine the evolution of recruitment of elites and to investigate the nature of the links between recruitment of elites and economic growth. The main change that occurred in the way the Western world trained its elites is that meritocracy became the basis for their recruitment. Although meritocratic selection should result in the best being chosen, we show that meritocratic recruitment actually leads to class stratification and autorecruitment. We analyze the consequences of stratification resulting from meritocratic selection for the development of a country, and show that these consequences are dependent upon the type of technological changes occurring in the country.
\end{abstract}

JEL Code: I21, O15, O40.

Keywords: economic growth, education, elites, meritocracy, recruitment, social mobility, stratification.

\author{
Elise S. Brezis \\ Department of Economics \\ Bar-Ilan University \\ Ramat Gan \\ Israel \\ brezie@mail.biu.ac.il
}

\author{
François Crouzet \\ University of Paris IV \\ Sorbonne \\ Paris \\ France \\ frcrouzet@neuf.fr
}

We wish to thank Philippe Aghion, David de la Croix, Theo Eicher, Oded Galor, Zorina Khan, Cecilia Garcia Penalosa, Gerard Roland, Kenneth Sokoloff, and Peter Temin, as well as participants at the Cesifo workshop in Venice for their helpful comments. 


\section{Introduction}

Higher education institutions have seen much turmoil over the past few centuries. For long, universities were part of the religious establishment, and their main role was to teach liberal arts, philosophy, and theology, though some of them became famous for specific subjects, such as law in Bologna and medicine in Montpellier. Most university students, whose numbers were in any case few, were preparing for a career in the Church, even after the Reformation. Then, in the nineteenth and early twentieth centuries, universities underwent reform; they generally became secular, and they started to teach new subjects, particularly the sciences. Still, a university degree was not necessary for a career, except in a few specific professions.

During the last half of the twentieth century, a dramatic change took place in higher education: The number of universities and colleges in the West rose, and the number of students increased even more. Concurrently with this democratization of higher education, universities became heterogeneous not only in their specializations, but in their quality. When higher education is provided only to a fortunate few, there is no need for selection, and universities do not differ in their quality and prestige; yet when higher education is democratized and nearly $40 \%$ of the population attends colleges or universities, uniformity in their quality is impossible. There is, therefore, a distinction between on the one hand, the elite universities, for which after World War II, selection became meritocratic, and on the other hand, the rest. ${ }^{1}$

These changes in higher education that occurred in the twentieth century affected the way in which elites were recruited. While before World War II, elites had rarely been educated at universities, after World War II, they attended elite universities, and the criterion for their recruitment became graduation from elite schools. In consequence, post-World War II, elites are recruited through education in elite universities to which admission was conferred following success at meritocratic exams.

The purpose of this paper is to examine the effects of this meritocratic recruitment of elites on class stratification and economic growth. We first show that recruitment to a university via a meritocratic method based on entrance exams does not lead to enrollment from all classes of society according to distribution or ability, nor does it necessarily lead to the admission of the most talented. Recruitment by entrance exam still encompasses a bias in favor of elite candidates, because this type of exam requires a pattern of aptitude and thinking that favors candidates from an elite background.

\footnotetext{
${ }^{1}$ Today, not only does a degree affects the remuneration and career path of students, but also largely the prestige of the university or college from which they graduate.
} 
In this paper, we show that even a slight cultural bias can lead to more than half of students enrolled in elite universities coming from an elite background. This cultural bias, which can be included in the typology of environmental factors, has a magnification effect on class stratification. ${ }^{2}$ Therefore the resulting student body is a mostly homogeneous group that is not as open as it should be to the non-elite public, despite the meritocratic selection method of the elite universities. In other words, we show that an elite education leads to a "non-circulation of elites". ${ }^{3}$

Although meritocratic selection should result in the best being chosen to enter the top ranks of public service or business, the framework described herein allows us to show that elite schools and universities have a tendency to recruit in a non-diversified way, resulting in certain classes being over-represented. Our model emphasizes that despite meritocratic recruitment, elite universities actually recruit from the "aristocracy", and we get a resulting "stratification" of recruitment. In consequence, the fact that over time, individuals from the same background are accepted to elite universities is due not to cronyism, but to the system itself, despite the fact that it is meritocratic.

We then examine the consequences of meritocratic recruitment on economic growth. The recruitment of the elite affects the economy, as it affects the quality of leaders: Having the best citizens as leaders enables efficient and correct choices. We show that the effects of meritocratic selection are dependent on the type of technological changes occurring in the country in question. During times of innovation, i.e., minor changes in technology, the elite schools optimally fulfill their purpose, since the aptitude acquired at home by the children of the elite class is an advantage regarding the type of technology in use. These students therefore perform better on average than students recruited from the non-elite population. Thus, the non-circulation of elites in this case does not hamper growth.

But during times of invention, i.e., the emergence of totally new technologies, aptitude acquired via family education is useless, and so lack of circulation of elites is detrimental to the adoption of new technologies. Therefore, in an era of invention, the recruitment of the elite from elite schools actually leads to a lower growth rate.

\footnotetext{
${ }^{2}$ In this paper, we do not include heredity (emphasized by Herrnstein and Murray, 1994) as one of the factors leading to class stratification, but only environmental factors as cultural bias.

3 "Circulation of the elite" is an expression coined by Vilfredo Pareto in 1902, who claimed that the elite, in recruiting itself, chose subjects of increasingly mediocre caliber: "Merely a slowing down of this circulation may have the effect of considerably increasing the number of degenerate elements within the classes still possessing power, and -- by contrast -- of increasing the number of elements of superior quality within the subject classes... The decadence originates from the fact that the elite, in recruiting itself, chose subjects of increasingly mediocre calibre" (Vol. 1, Introduction).
} 
This paper is divided into five parts. In the next section, we present a short survey of the evolution of elite recruitment in the Western world. In Part III, we analyze the effects of meritocratic exams on stratification; Part IV examines the effects of meritocracy on economic growth; and Part V concludes.

\section{Recruitment of the Elite in the Twentieth Century}

The main shifts in the recruitment of elites took place in the second half of the twentieth century, and are related to meritocratic selection. However, this was not the first time that changes occurred in the way elites were recruited. Before introducing the facts on recruitment in the twentieth century, we present a concise survey of the recruitment and training of elites in earlier times. ${ }^{4}$

\section{A. Before the Industrial Revolution}

Over the centuries, there have been changes in the way the Western world has recruited its elite. As early as Biblical times, Jethro, Moses' $\equiv$,father, suggested to him that he should find elite people by looking for “...distinguished men, fearing God, liking truth and enemies of luxury" (Exodus, 18:21). Later on, when the first king in the Bible was to be chosen, the Prophet Samuel ordered that the King should be selected by lot, in a random way (Samuel I, 10:20). The subject of selecting the elites had also been discussed by the Greek philosophers. Aristotle stressed that a city should be ruled by the best ("aristoi" in Greek), and that government should be in the hands of the most able members of society. They should be highly intelligent and educated (as well as brave and temperate) citizens. For Plato and Aristotle, the recruitment of the elite was a crucial element in determining optimal political structure.

Despite this enlightened view, over the centuries, recruitment of the elite was actually carried out via heredity, nepotism, and violence, and the word "aristocracy" came to describe the hereditary upper ruling class. Hereditary monarchy was for centuries considered the most legitimate means of recruitment for rulers, based on the assumption that morality and intellectual prowess are inherited, according to God's will. In traditional European societies until the nineteenth century, membership in the elite was mainly hereditary; noble birth was the rule. Moreover, highly born people were also generally wealthy, even though their wealth was mainly landed. In consequence, the upper elite was made up of large landowners, an état de fait which was normal in agrarian societies. Appointments to various state positions (including the armed

\footnotetext{
${ }^{4}$ For a more detailed description, see Brezis and Crouzet, 2004.
} 
forces and the Church) were made either by patronage or by purchase. Patronage was a matter of family connections, favor, and intrigue.

Nevertheless, there were some channels through which new people emerged regularly into the elite: the favor of the sovereign or of some great lord, military prowess and exploits, amassing wealth through trade or, frequently, involvement in government finance (such as tax farming), and purchase of public offices. ${ }^{5}$ Such upward channels involved some meritocratic elements; this was particularly pronounced within the Catholic Church, where some rose as a result of sheer intellectual prowess.

Education was not a necessary element for entering the elite, and there was no specific education for the elite, although most sons of the nobility had private tutors. From the seventeenth century onwards, many of them were sent to "high schools" such as the English public schools, or in Catholic countries, colleges run by the Jesuits or the Oratorians. In these schools, pupils received a purely classical education.

\section{B. From the Eighteenth to the Twentieth century}

Changes in the recruitment and training of elites first took place in the late eighteenth century, arising from the needs of modern states. Military schools and various other institutions, such as the French grandes écoles were established for training experts, although only a small proportion of the elites went through these schools and universities at this period.

Then, in the late nineteenth century, in Europe as well as in the USA, two major economic changes had a strong impact. The first was the "second Industrial Revolution", i.e., the rise of new industries, like chemicals and electricity, which were science based. The second was the rise of the "corporate economy", and of the Chandlerian managerial enterprise that led to the process by which salaried senior managers largely took over from capital owners and heirs of the founding families. Both engineers and managers needed specialized formal training, while the pioneers of industrialisation and their heirs only had had on the job training. So there was a clear difference between the education of the leaders of the First and of the Second Industrial Revolutions (Kaelble, 1979, p.29).

On the whole, the late nineteenth and early twentieth centuries saw major changes in the education of the elite, and institutions were reformed or created to provide such training. In most countries, the old "medieval" universities were reformed and expanded during this period, and many new ones were established.

\footnotetext{
5 Such rises were generally crowned by ennoblement, thanks to which descendants of the "new men" were - after a time - fully integrated into the elite.
} 
In England, in the late nineteenth century, new or "red bricks" universities had been established in provincial cities; they emphasized science and technology and also had schools of commerce. However, the proportion of business leaders who graduated from universities others than Oxbridge was low for a considerable period, and for well-born young men, universities such as Oxford and Cambridge were merely "finishing schools" where they had a good time and made useful connections. Moreover, a large majority of business leaders -- especially in the City, and somewhat less in industry and commerce -- had attended public schools before entering university; indeed education at a major public school was more important in terms of social prestige that a university degree.

In France, the most original character of the system for recruiting and training elites was the role played by elite institutions -- the Grandes Ecoles (GE), and more specifically the Ecole Nationale d'Administration, best known by its abbreviation -- ENA. The origins of the GE go back to the eighteenth century military schools, and to the creation of special schools to train engineers, that the state needed: the Ecole des Ponts et Chaussées (for civil road engineers) was established in 1715, and the Ecole des Mines (for mining engineers) in 1783. During the French Revolution, the need for more civil and military engineers was felt. In 1794, the Ecole Polytechnique was established.

During the nineteenth and the twentieth centuries, a large number of other GE were gradually established, mainly for training engineers, as Ecole Centrale in 1829 (a school to which, after 1840, a significant number of French industrialists sent their sons), but also for giving commercial training, particularly HEC (Hautes Etudes Commerciales) in 1881, which can be described as the first French business school. This proliferation resulted partly from deficiencies in the French university system.

During the nineteenth century and at the beginning of the twentieth, there were differences between countries in the importance of education and training of elites. In England, business leaders, most of whom had not had any higher education, were wary of university graduates. This suspicion reflected the cult of the "practical man", ${ }^{6}$ and therefore, most of the British economic elite was recruited and trained via the traditional channels of family connections and patronage, the so-called "old boys' networks" of those who had attended public schools.

In some respects this system survived into the twentieth century. A high, though decreasing, proportion of top British executives began their careers at the end of their secondary education; they were either "heirs", i.e., members of the family that owned the firm and sons of other "good families", who received a top job at once, or men from a more modest background, who had risen within a firm. However, it became increasingly frequent for upper- and upper-middle class

\footnotetext{
${ }^{6}$ See Rubinstein, 1993.
} 
young men to attend university before entering business. In consequence, the percentage of university-educated British executives was lower than in France and Germany, especially in the first half of the twentieth century, but increased over time. From the inter-war period, large firms increased their intake of university graduates, many of them from the older universities (especially Cambridge, which had placed greater stress upon the teaching of science and even engineering).

As for the US, until the end of the nineteenth century, the situation was not that different. Elite members were either heirs, children of rich men who inherited the family firm, or newcomers to the business world who made their fortunes through their own exertions. As in other countries, few of these "self-made men" were of truly proletarian origin, and most came from the lower middle class and the labor aristocracy. In any case, such men, ipso facto, had had very little formal education.

Most of the "heirs" had attended secondary school, had entered the family firm at about age 16 , and learned on the job. It was widely believed that further studies -- especially at a university or college -- would be a waste of time and even bad for business, and that direct contact with the latter was desirable as early as possible. Therefore, higher education seemed irrelevant for most professional callings. Until the 1870 s, young men who were to follow a business career did not attend universities.

From the turn of the twentieth century, there was a gradual change in the recruitment and training of elites. ${ }^{7}$ An increasing number of large companies started to hire people who had received academic education. In the 1890 s, the need for managers who had undergone serious and thorough training was felt, and graduates from the new business colleges, which had been recently established, were hired in large numbers. ${ }^{8}$ The founding, in 1908, of the Harvard School of Business Management and the creation of the MBA sanctioned this development. During the same period, graduate schools of law and medicine were established in the major American universities.

\section{The Second half of the twentieth century}

The recruitment of elites changed dramatically after World War II. In all countries, there was a desire on the part of politicians to "democratize" the elite, and in consequence, there were significant reforms in the way the elites were recruited, as well as in their education.

\footnotetext{
7 The change was gradual and clerkship still long remained the usual form of apprenticeship for a business career.

8 As early as the $1870 \mathrm{~s}$, an increase took place in the number of colleges and students. The number of undergraduates rose from 52,000 in 1870 to 238,000 in 1900 , and that of graduate students in doctoral programs from 50 to 6,000 .
} 
After World War II, while a "democratization" of higher education took place, reflected by an enormous increase in the number of university students, there was a concurrent emergence of two channels of education: one for the elite and the other for the rest. This was emphasized by University of California President Clark Kerr, who set the stage for university for all, but the elite university for the best. ${ }^{9}$ In consequence, the elite was trained in elite colleges. This evolution was described by Temin for the US $\equiv$ was able to identify the colleges attended by 454 CEOs of the Fortune 500 companies. All current business leaders on whom I could find information attended college..and almost one-fifth graduated from the Ivy League" (Temin, 1999a, p.32). ${ }^{10}$ By the early 1960s, those who had not attended college were precluded from becoming part of the business elite. ${ }^{11}$

In the US, the changes took place mainly during the 1940s. Until then, there was a group of people who constituted the Establishment: they were male, white, and Protestant (mostly Episcopalian). They were the elite, their children attended the elite universities, and few others could attain any power. ${ }^{12}$ Indeed, education at an Ivy League university was the entry ticket to the elites of all kinds (except the political elite, which was more a melting pot), and before 1936, recruitment to universities was based on family and geography.

There was, therefore, a widespread desire to break the hold of this old elite and replace it with a new elite that would be made up of people from a broad range of backgrounds from all over the country, selected on the basis of intelligence and not birth. There was a need to replace the "aristocratic" and non-democratic elite with a "brainy" one that would lead the country. This desire was already expressed by Thomas Jefferson more than a century before: "..There is a natural aristocracy among men. The grounds of this are virtue and talents... while the artificial aristocracy is founded on wealth and birth". ${ }^{13}$

As already emphasized above, this wish to find the "natural aristocracy" is not specific to the US, and has equivalents in Europe, especially in France. However, the American meritocratic way of selecting the most intelligent in order to recruit the best public servants, and let them run the country is different from the French one. While France opted for the system of the grandes

\footnotetext{
${ }^{9}$ Kerr wanted UC-Berkeley to become a highly selective, world-class university with a star faculty that would train the elite of California, which would be selected by testing, while the other colleges would accept all other applicants.

10 Of the 800 chief executives running the largest US public companies in 2003, 87 had MBAs from the three top business schools - Harvard, Stanford and Wharton (see Forbes Global, October 13, 2003, p.28).

11 On the other hand, in a recent development, the Information Technology Revolution (ITR) has offered opportunities to new entrepreneurs such as Bill Gates to rise quickly in the business world without graduating (but also for some, to fall fast later on). Yet unlike the tinkerers of the Industrial Revolution, such entrepreneurs need a strong scientific education.

12 See Miller (1949, 1950). Taussig and Joslyn (1932, p. 240) have shown that in 1930, 80\% of the business leaders came from the top $7 \%$ of the population.

${ }^{13}$ A letter to John Adams in 1813 (see Cappon, 1959).
} 
écoles already existing, and that were based upon achievement exams, the US adopted SAT exams.

The SAT, or Scholastic Aptitude Test (itself an adaptation of the army intelligence test called the Army Alpha) was developed at Princeton University, and placed the emphasis for university admissions on aptitude instead of achievement. ${ }^{14}$ The system was slowly adopted by all universities. It was adopted first by Harvard -- run at that time by James Conant -- who supported a selection process which would lead to the recruitment of his university elite from all social classes, and who felt that achievement tests were unfair to poor children because most had not attended good high schools. Therefore, he called for a system for choosing the meritocracy that was not based on achievement. Harvard thus adopted the SAT for use as a scholarship test during the 1930s; its use then spread as a scholarship test for all Ivy League schools. It took 20 years for the SAT to become a requirement for all applicants to the University of California, and soon afterwards to all Eversities. Standardized testing provided the basis for selection to elite universities. ${ }^{15}$

However, despite the wish to democratize selection, SAT scores were correlated with family education and wealth. ${ }^{16}$ Meritocracy did not mean democratization and opportunity for all. The unrealized dream of the virtue of meritocracy as opposed to aristocracy, has been emphasized by Temin. He has shown that the US economic elite is still overwhelmingly made up of white Protestant males, a significant number of whom were educated at Ivy League institutions. The picture has not changed significantly from c. 1900: "The American business elite comes from elite families" (Temin 1999a., p.33), just like in France or Britain. ${ }^{17}$ The fundamental irony of the American meritocracy is that the system finally favored the elite's children. The wish that America would become a classless society through the use of aptitude tests did not come true: meritocracy led to aristocracy.

In consequence, in order to reduce stratification, the US has an elaborate selection system for minorities, trying to advance the best persons under an affirmative action system that can be

14 It was developed by Carl Brigham, a psychologist (see Brigham, 1923). It is a type of general intelligence test, and the verbal portion is similar to an IQ test. It was created and administered by the ETS, the Educational Testing Service, a privately funded, non-profit organization. For more details on the history of SAT (see Lemann, 1999).

15 There was a fierce debate about the success of ability tests as the basis for meritocracy. For the argument against such tests, see Hoffman (1962), and also Nairn and Nader (1980), while Gardner (1995) presented a plea in favour of these tests. See also Jensen, 1989.

16 Research on the variables affecting SAT results is numerous. See in particular Bouchard and McGue (1981), Neal and Johnson (1996), and also Hernnstein and Murray (1994).

17 Although the percent of workers entering the elite class in the 1960s was double in the US as compared to Britain, France and Germany (Blau and Ducan, 1967). As noted by Temin (1999a, p.32) and Kingston and Lewis (1990, p.111): "Approximately one quarter of 1986 college freshmen at highly selective universities come from families with incomes over $\$ 100,000$, that is, from the extreme upper tail of the income distribution." It should be noted that this lack of change in the economic elite occurred despite the fact that the makeup of the political elite has markedly changed over the century. 
seen as a "patch" on meritocracy to make it run better. Meritocracy is a sort of particular system of picking people for the elite based on one set of abilities, while affirmative action is trying to twist the dials a bit to get more minority representation into the meritocratic elite.

In France, despite a different system of recruitment, the situation is somewhat similar. The grandes écoles (GE) and especially the ENA play a role similar to the Ivy Leagues universities in the US: they are elite schools, and very selective. Indeed, France presently has 302 engineering schools with 59,000 students and 226 commerce or business schools with 64,000 students. These figures may be compared with the million and a half of students in universities, which have no entry exam and admit anyone who has graduated from high school (baccalauréat).

At the competitive exam (concours) to enter a grande école, the number of candidates accepted every year is fixed. ${ }^{18}$ Moreover, one does not sit for the concours just after high school; students first go to specialized schools (classes préparatoires) where they are only accepted if they had good grades in high school or at the baccalauréat. They study intensively at the classes préparatoires for one to four years, after which they take the entry exam for one or several of the grandes écoles. ${ }^{19}$ Thus, of the half a million people who succeed in the baccalauréat each year, 36,000 are accepted in the classes préparatoires, among whom only 25,000 will eventually enter a GE in the next few years.

The GE have, over time, become increasingly important to the recruitment of the French business elite. From 1920 onwards, over $50 \%$ of a sample among the leaders of French industry had graduated from engineering schools, and the percentage had reached $70 \%$ in 1939 . According to Lévy-Leboyer (1979, Table 6. pp. 160-1), amongst a cohort of business leaders over the period 1912-79, 29\% of them had graduated from Polytechnique.

A very specific GE, which has over time become the most elitist of the elite schools, is the ENA. This school is the main channel for recruiting the elite. Forty-seven percent of the heads of the 200 largest French companies in 1993 came from the civil service (and have been through ENA). In 1997, 55\% of the leaders of French CAC 40 firms came from the civil service (see

\footnotetext{
18 In all these schools, the number of entrants was, and is not large: the students admitted per year in the five biggest engineering schools were 320 in 1860, and 1176 over the period 1919-1932 (see Lévy-Leboyer, 1979, p.152).

19 Moreover, there is a hierarchy among GEs; the first rank schools are usually in Paris. There is a wide gap in prestige and also in job opportunities for graduates between GE of the first rank -- Polytechnique, Centrale, HEC, and provincial commerce schools. There is also a hierarchy between classes préparatoires for the main GE. Actually those which are located in three or four big high schools on the Paris left bank supply a large majority of students who succeed at the exams for GE of the first rank. The fate of students who fail at the concours is to enter university, where they do well thanks to their intensive work in a classe préparatoire. Moreover, groups of engineers' schools have a common exam, and candidates who do not well enough to be accepted to the top GE can enter the less prestigious ones.
} 
Baverez, 1998). ${ }^{20}$ It is also the entry to the political elite. Indeed, from 1980 onwards, 35 percent of ministers had attended ENA. ${ }^{21}$

The main goal of ENA when it was created was to make changes in the recruitment of the French bureaucratic elites. Indeed, at the end of World War II, the government and, more precisely, General De Gaulle considered that there was a need to change the recruitment and training of civil servants. It was thought that since recruitment would be meritocratic, only the best would be selected. They would come from all classes, in contrast to the previous system for recruiting which was restrictive from a social point of view. So the goals of recruitment to ENA was social openness, diversification of intellectual origins, and developing a new elite that would be chosen for their talent rather than their link to the elite in power.

The selection for ENA is more drastic than the other GE: students have to jump over two fences -- an entry exam and a final exam, and the last one is decisive. The department in which an alumnus (énarque) begins his employment, from the most prestigious ministries to the least attractive, depends on his ranking in the final competitive exam at the end of the second and last year.

As for the entrance exam, the early design to democratize recruitment was embodied in the creation of two separates exams. One is for "students", i.e., graduates coming directly from university (generally from law and humanities) or from an IEP (institut d'études politiques). The major IEP which is situated in Paris is usually known as Sciences-Po. The quality of teaching is high and Sciences-Po is really the main channel towards ENA. After graduating, would be candidates spend a year or two in special classes, whey they are coached for the ENA exam and which are the equivalent of the classes préparatoires for the other GE. As for the written exam, it is largely a matter of broad general culture, though writing some papers on subjects like economics or international relations is required. At the oral exams, the ability to speak brilliantly about a subject one knows nothing about is crucial!

The second exam is reserved for candidates who have spent some years (at least five) in the lower ranks of the civil service; but they must have a university degree, and generally they have been coached for one year in special classes (like the candidates for the first exam). This exam is separate but not very different from the first; it was intended to afford an opportunity for those with a more modest background than alumni from Sciences-Po to enter the ENA. ${ }^{22}$

\footnotetext{
20 Includes the shares of the 40 most important firms in France, the French Dow-Jones.

21 Presidents Giscard d'Estaing and Chirac, Prime Ministers Laurent Fabius, Michel Rocard, Alain Juppé and Lionel Jospin also went to ENA.

${ }^{22}$ As a matter of fact, and generally speaking, persons who entered the ENA through the bureaucrats' exam were less successful in their later careers than the ones taking the students' exam, because they did not do as well at the final comprehensive exam (which is the same for all students). Presently 60 percent of entrants are "students," and 40 percent "civil servants."
} 
When comparing the recruitment of ENA with other grandes écoles, the ENA recruits approximately 100 students each year, while Polytechnique recruits almost 500. Although other grandes écoles have a specific technical curriculum, the ENA focuses more on recruiting than on training the elite. ENA students spend their first year working as interns in some public agency (a regional administration or an embassy, for example). They then return to school for the second year, where the emphasis is again on humanities and social sciences (though in recent years the teaching at ENA has been mildly "technicized"). ${ }^{23}$

As for the democratization of recruitment, after World War II the first few promotions were open to all classes and open to reform. At that time, the ENA was synonymous with innovation and new blood in the administration, and there was a feeling that only the best were chosen. Twenty years later, however, it was apparent that recruitment was sociologically and geographically narrow. The proportion of students in the ENA whose parents belonged to the elite ( $8 \%$ of population) was $44 \%$ in 1950 , and rose to $63 \%$ in $1980 .{ }^{24}$ Thus, starting in the 1970 s, an auto-recruitment of the ruling class has taken place, since $8 \%$ of the population supplies $63 \%$ of the ENA students, or the next generation of rulers.

Altogether, France has a system which is drastically selective, highly elitist and in which the selection becomes even more severe over time. Moreover, the number of GE students is very low compared to the total number of students in universities, and is stable while the number of students in universities has increased annually until recently.

In conclusion, in all countries, the education and training of the bureaucratic and business elite, until recently, had little relevance to their future working career. Education at the French grandes écoles and at English public schools or Oxbridge imbued a strong feeling of belonging to the elite and laid the foundations for vast networks of relationships.

From World War II onwards, the path to elite positions has required attendance at an exclusive school or university, in which recruitment is based on meritocracy. The two main differences between the French and American recruitment systems lay in the method of selection chosen. The first difference is in the type of exam: achievement tests (France) vs. aptitude tests (the US). The second difference is in the number of times selections are made, and the relative number of recruits. ${ }^{25}$

\footnotetext{
${ }^{23}$ It is commonly remarked that the internship during the first year is very useful, while students do not learn much during their second year at the school itself.

24 See Gaillard (1995, pp. 105-108). However, each graduating class includes a few persons from modest backgrounds, some of whom go on to brilliant careers.

${ }^{25}$ Another main difference is the tuition paid. While in the US, tuition at elite universities can run around $\$ 100,000$, in France, not only the universities and grandes écoles are almost free, but in the grandes écoles with a vocation of serving the state (Polytechnique, ENS and ENA), students are paid! Actually, many of them serve the state for a few years and afterwards enter the business world.
} 
In the US, university applicants take the SATs, and those earning the highest scores are usually admitted to the elite universities. Of 2,000 colleges, 50 are considered elite colleges (including the "Ivy League $\equiv$ In contrast, in France, of 450,000 students who obtain the Baccalaureat, only 36,000 enter the classes préparatoires, from which only 10,000 will reach the first rank of grandes écoles in the next couple of years. So in the US, the relative numbers of such "favorites of fortune" are higher than the graduates of the ENA and the grandes écoles.

However, both systems ultimately lead to a very narrow recruitment process. Both countries tried to react to this narrowing and stratification. The American reaction to its recruitment system was affirmative action for minority group members, whereas the French reaction to its system was the "second entry exam" for admission to the ENA, and open access to universities.

In the next section, we examine the reasons why elites are auto-recruited. Temin (1999b) has proposed three causes for auto-recruitment, which he terms "the stability of the elite": discrimination, signalling, and education. Temin rejects the first two, ${ }^{26}$ and concludes that unequal access to education might explain the demographic stability of the elite. ${ }^{27}$

In the next section, we show that recruitment to elite universities by meritocratic exams might be the cause of this stability of elites. We will also analyze how different recruitment methods as SAT or achievement tests affects stratification.

\section{The effects of meritocratic recruitment on social stratification}

In this section, in order to examine the effects of meritocratic exam on the intergenerational mobility of elites, we incorporate elements specific to recruitment in countries like the US and France. In France, there is an entrance exam to the elite schools (GE), based on very broad subjects rather than on specific technical knowledge; they are some sort of achievement tests. In the US, entrance exams are tests of ability and not achievement: the SAT.

\section{A. The basic framework}

As we have shown in the section above, the raison d'être of elite schools is to recruit the most capable students. If information were perfect, the exact value of a given applicant would be known, and elite schools would then choose the best candidates. However, since the information

\footnotetext{
26 Temin also rejects the possibility raised by Taussig and Joslyn (1932) of a fundamental inequality of native endowments.

${ }^{27}$ Indeed, primary and secondary education, especially in public or state schools, has fallen into crisis in all Western countries, owing to ill-conceived reforms, the breakdown of discipline, and the low quality of many teachers (see Temin, 2002). This markedly restricts opportunities for bright young people from modest backgrounds to excel in their studies, win scholarships, and attend university. In France today, only children from the middle class, or even upper middle class families can obtain a good high school education.
} 
available is imperfect, the best approximation is performance in the entrance exams. ${ }^{28}$ We will show that these meritocratic exams lead to class stratification.

Let us denote $\mathrm{P}_{c}$, the population of students who have finished high school and would like to enter elite universities (or classes préparatoires in France), and $\mathrm{E}_{\mathrm{c}}$, the population of students who belongs to the elite milieu ("children of") and wish to enter elite schools. We denote $\mathrm{E}_{\mathrm{s}}$ as the population of students belonging to the elite milieu who entered the elite schools, and $\mathrm{P}_{\mathrm{s}}$ the whole population of students who entered the elite schools. In consequence the ratio of potential students from elite milieu to the potential student population, $\mathrm{P}_{\mathrm{ep}}$ is:

$$
\mathrm{P}_{\mathrm{ep}}=\mathrm{E}_{\mathrm{c}} / \mathrm{P}_{\mathrm{c}}
$$

and the ratio of students belonging to the elite milieu who entered the elite schools to the total student population, denoted $\mathrm{P}_{\mathrm{es}}$ is:

$$
\mathrm{P}_{\mathrm{es}}=\mathrm{E}_{\mathrm{s}} / \mathrm{P}_{\mathrm{s}}
$$

Denoting as $\beta$ the ratio of the percentage of the elite children in the elite school over the percentage of elite in the total population, then:

$$
\beta=\mathrm{P}_{\mathrm{es}} / \mathrm{P}_{\mathrm{ep}}
$$

$\beta$ is in fact the parameter which measures the amount of auto-recruitment and stratification in the economy. When $\beta$ is 1 , then the percent of children from the elite milieu in these elite schools is equal to the percentage of the elite in the population, which means that there is no auto-recruitment and the system is totally democratic. When $\beta$ is greater than 1 , that is $P_{\text {es }}$ is greater than $\mathrm{P}_{\mathrm{ep}}$, there is auto-recruitment; and the bigger $\beta$, the greater the stratification effect in this economy. We will now show, how meritocratic exams affect $\beta$.

We define $I \mathrm{E}[0,1]$ as the minimum grade necessary to be accepted to the school. If the grade $\alpha_{i}$ of student $i$ is greater than $I$ he is accepted to the elite school:

$$
\alpha_{i}>I \text {. }
$$

The performance of a student on the test is based on two elements. The first is his ability; more able students get better grades at their exams. We assume that the ability $a_{i}$ for all students

\footnotetext{
28 Moreover, tests also display a reliability problem, i.e., that there is similarity in a given subject's exam scores on
} different runs of the exam. We discuss this problem below. 
is uniformly distributed on [0,1], i.e., whatever the social class, the ability is distributed uniformly. ${ }^{29}$

The second element takes into consideration that tests are not perfectly objective, but reflect a culture related to the milieu of the elite with which the examiners for a school are associated. Therefore, students with an equivalent ability, but who are born to the elite and raised in this milieu, will perform better on tests.

The grade of student $i$ who is not part of the "elite milieu" corresponds to his inherent ability, while the grade of a student from a family in the elite incorporates not only his ability, but also the cultural background from his family -- the inside knowledge specific to the elite milieu, which we define as $f .{ }^{30}$ Without loss of generality, we assume that the relation is linear, the grade the student receives is therefore:

$$
\begin{array}{cl}
\alpha_{i}=a_{i} & \text { for student } i \text { outside the elite system, } \\
a_{i}+f & \text { for student } i \text { being raised in the milieu. }
\end{array}
$$

Since for the whole population, the success is only due to ability, then the percentage of accepted students from the entire population denoted $\gamma_{\mathrm{p}}$ is 1-I:

$$
\gamma_{\mathrm{p}}=\mathrm{P}_{\mathrm{s}} / \mathrm{P}_{\mathrm{c}}=1-\mathrm{I}=\lambda
$$

where $\lambda$ is defined as $\lambda=1-\mathrm{I}$. $\lambda$ is a factor that represents the tightness of enrolment. We will show that $\lambda$ affects the size of the stratification effect.

For the students of elites milieu, f affects the percentage of accepted students, $\gamma_{\mathrm{E}}$, which is:

$$
\gamma_{\mathrm{E}}=\mathrm{E}_{\mathrm{s}} / \mathrm{E}_{\mathrm{c}}=1-\mathrm{I}+\mathrm{f}=\lambda+\mathrm{f}
$$

Recall that $\beta$ is the ratio of the percentage of the elite children in the elite school over the percentage of elite in the total population, then:

\footnotetext{
${ }^{29}$ As mentioned above, the bias is only due to cultural background. We are aware that some empirical results show that ability is not uniformly distributed (Herrnstein and Murray, 1994), and some theoretical models explaining why effort, and therefore ability, would be different in the different social classes (see Durlauf, 1999, and Arrow et al., 2000). However, the assumption that ability is uniformly distributed is often adopted in models on mobility; see, for instance, Galor and Tsiddon (1997).

30 The problem of reliability of exams can be incorporated in the parameter $\mathrm{f}$. Exams such as those in France are subject to reliability problems higher than the SAT, due to subjectivity problems. Moreover, students who are not "great" but on this particular day felt well would be accepted, while some more brilliant were not, because it was not the subject in which they were good at, or it was not the right day. This problem is less acute in the US.
} 
$\beta=\mathrm{P}_{\mathrm{es}} / \mathrm{P}_{\mathrm{ep}}=\gamma_{\mathrm{E}} / \gamma_{\mathrm{p}}$

Therefore:

$\beta=(1-I+f) /(1-I)=1+\frac{f}{\lambda}$

Equation (9) shows that $\beta$ is a function of $f$ and $\lambda$. As explained earlier, $\beta$ is the parameter which measures the amount of auto-recruitment and stratification in the economy; when $\beta$ is greater than 1, we get a decrease in diversity of elites and an auto-recruitment. This framework permits us to show that a very small cultural bias (small f) will lead to a strong effect on class stratification, as underlined in the next proposition:

\section{B. The Results}

Proposition 1

(i) A school for elites based on meritocracy leads to class stratification. The parameter of auto-recruitment, $\mathrm{f}$, is related to cultural bias and tight recruitment level. An increase in one of them lead to an increase in class stratification. A small cultural bias brings about that children born in the elite are represented by much higher percentages than their ratio to the population.

(ii) Assuming that ability tests are less prone to subjectivity than achievement tests, the system of recruitment by ability tests leads to less stratification than achievements tests.

(iii) Countries with tighter recruitment level (I higher) will have more stratification.

(iv) Having two levels of recruitment tests lead to less stratification than one test.

Proof

Homogeneity and stratification is measured by $\beta$; the bigger $\beta$, the greater the stratification effect in this economy. Since $f / \lambda$ is greater than $0, \beta$ is greater than 1 which means that $P_{e p}$ and $P_{e s}$ will not be equal, and despite meritocratic exams, stratification exists.

Moreover, from equation (9), the higher $\mathrm{f}$, the greater $\beta$. On the other hand the higher I, the lower $\lambda$ and therefore $\beta$ is bigger.

Part (iv) is somehow counter-intuitive. In the case of two levels of exams as in France, equation (9) becomes:

$$
\beta=\left(\lambda_{1}+\mathrm{f}\right)\left(\lambda_{2}+\mathrm{f}\right) / \lambda_{1} \lambda_{2}=1+\frac{\mathrm{f}\left(\lambda_{1}+\lambda_{2}+\mathrm{f}\right)}{\lambda_{1} \lambda_{2}}
$$


Comparing equations (9) and (10) by taking as equal the level of recruitment (i.e. assuming that the percentage of students recruited is the same $\left(\lambda_{1} \lambda_{2}=\lambda\right)$ then $\beta$ of equation (10) is smaller than that of equation (9) since we assume that the sum $\left(\lambda_{1}+\lambda_{2}+f\right)$ is smaller than one.

This proposition states that stratification is a consequence of the advantage to the students raised in the elite milieu due to their cultural background, $f$. To give a sense of magnitude to our parameters: for $\mathrm{f}$ of 0.07 -- the milieu gives an advantage of 7\% (which does not seem a large number, since it seems very reasonable to assume that children raised in the elite get an advantage of around $10 \%$ ), this will lead to $\beta=8$ (by assuming that $I=0.99$, which is the case in France).

A stratification effect, $\beta$, of 8 means that the percentage of children from the elite milieu who are accepted is 8 times higher than the percentage of children from the total population. In other words, if the elite represents $8 \%$ of the population $\left(\mathrm{P}_{\mathrm{ep}}\right)$, then the elite milieu will supply $64 \%$ of the students in the elite schools $\left(\mathrm{P}_{\mathrm{es}}\right)$. This matches perfectly the facts found for France, since in part II we have shown that $8 \%$ of the population supplies $63 \%$ of the ENA students, which corresponds to a $\beta$ of 8 . So a small advantage for the elite milieu of $7 \%$ leads to a major auto-recruitment effect as found for France.

This simple model shows that the fact that, over time, individuals from the same milieu are accepted to a school for elites is not due to cronyism, but to the system itself, even if it is meritocratic. Elite schools freeze the circulation of elites. Auto-recruitment and stratification are not due to some favoritism, but to imperfect information on the true value of students.

No system can be perfect when there is imperfect information on the genuine talent of people. Recruitment by education and exams automatically advances those who are educated inside the system. Thus, under imperfect information, selection of students through tests leads to a bias, i.e., for the same objective ability, students who are not part of the elite milieu will not be accepted, while a student of the milieu will be.

Parts (ii) to (iv) of proposition 1 permits us to compare the levels of stratification in France and the US. Indeed, the exams in France are based on achievements and knowledge tests vs. SAT tests in the US. It means that in France $\mathrm{f}$ is higher than in the US. Moreover $\lambda$ is higher in the US, since in France recruitment levels are tighter. However, the two levels of recruitment that exist in France lead to an opposite effect. So, the difference between these two countries is not unidirectional, but the two first effects seem more important and we can therefore conclude that the system chosen in the US leads to a lower $\beta$, i.e., to lower auto-recruitment than in France.

This effect of stratification and auto-recruitment due to meritocratic exams takes place only over time, and equation (9) is representing the value of stratification in steady state. However, 
when the system of meritocracy is put in place and is a "new system", then there is no stratification. When new schools are emerging, there is no bias in favor of the elite, and therefore in this case we get that $\beta$ is equal to 1 .

The fact that a bias does not exist when a new system of recruitment occurs may explain why after World War II, there was higher social mobility than in the 1930s. However, in the 1980s and 1990s, as shown by proposition 1, there is much less social mobility toward the top.

In this section, we have analyzed the effect of meritocratic recruitment on stratification and formation of elites. We now turn to analyze the impact on output.

\section{Meritocracy and economic growth}

We assume that the quality of the elites has an influence on the level of output, since they are in power positions and take decisions affecting the economy. We therefore assume that output is a function of the factors of production: capital, $K$, and labor, $L$; of the technology level, $A$, and the average quality (that we term "value") of the elites, $\bar{V}$, as displayed in equation (11). 31

$$
Y=A \bar{V} F(K, L)
$$

So the productivity level is a function of the value of the elites, $\bar{V}$, and of technological progress, $A$. Technological progress can be due to a change in techniques strictly speaking, but it also includes changes in processes of production, business culture and methods of management. The evolution over time of technological progress takes two different forms: innovation and invention. ${ }^{32}$ Innovation occurs in the context of a given technology; it leads to an increase in productivity based on the current technology and infrastructure (bureaucratic, technocratic). In this type of progress (built on the same structure), the value of students who come from the elite milieu has a value added, $f$, since they already are familiar with this structure. We can therefore write that the value of a student $i$ in time of innovations, $\mathrm{V}_{\mathrm{i}}^{\mathrm{n}}$, is a function of its ability as well as the education and culture received in its family environment, and without loss of generality, we assume that the influence of the milieu, $f$, enters $\mathrm{V}_{\mathrm{i}}^{\mathrm{n}}$ linearly.

\footnotetext{
31 see Brezis and Crouzet, 1999.

32 We use the typology formulated by Arrow. The effects of these different types of technology on the economy were already analyzed in other models (see Brezis et al., 1993; and Galor and Tsiddon, 1997). However they were not incorporated in an analysis of the recruitment of elites.
} 


$$
\begin{array}{ll}
V_{i}^{n}=a_{i} & \text { for } i \text { outside the elite system, } \\
& a_{i}+f \quad \text { for } i \text { being raised in the elite milieu. }
\end{array}
$$

The other type of progress is inventions. While innovations are based on previous technology, major breakthroughs that change the nature of technology fundamentally require that one starts anew and most previous learning is lost. This means that the culture the elite has assimilated in his home is no longer useful (in some cases it could even be counterproductive, but not in this model). So the value of a student $i$ in periods of inventions, $\mathrm{V}_{\mathrm{i}}^{\mathrm{v}}$ is a function only of its ability (and not of its family environment), so that:

$$
V_{i}^{v}=a_{i} \text { for all } i
$$

Thus, in periods of innovation the students' value is distributed on $[I, 1+f]$, while in periods of invention it is distributed on [I-f, 1]. (Since the students' ability is, in all cases, distributed on $[I-f, 1]$.) The average value of elites in periods of invention ${ }^{33}$ and innovation is respectively:

$$
\begin{array}{lll}
\overline{\mathrm{V}}^{\mathrm{n}}=(1+\mathrm{f}+\mathrm{I}) / 2 & \text { for } & \text { innovation, } \\
\overline{\mathrm{V}}^{\mathrm{v}}=(1-\mathrm{f}+\mathrm{I}) / 2 & \text { for } & \text { invention. }
\end{array}
$$

The interpretation of equation (14) is that during periods of innovation, but not of technological revolution, the students from the elite milieu contribute an average value of $(1+f+I) / 2$, which is a higher value than the average population accepted in the school $(1+I) / 2$. Those from the elite milieu increase the average value of the elite in times of innovations, and this results in a higher output (or growth rate). By contrast, during periods of inventions, i.e., of technological revolutions, the home culture is not useful, and only pure ability has an effect on output. The students from the elite milieu reduce the average ability and therefore reduce the average value of the elites. We summarize this effect in proposition 2.

\section{Proposition 2}

When the world faces innovations, the best elite is the one coming from the elites' schools; but, when the world faces inventions and big changes, diversity of elites is optimal. Homogeneity is, therefore, bad for growth, and elites schools are not optimal. Non-circulation of elites

\footnotetext{
${ }^{33}$ In equation (14), the average value of elites is given only for students belonging to the elite milieu, and we did not take into consideration the other students, since their average value, during periods of inventions or innovations, is always $(1+I) / 2$.
} 
resulting from elite schools hampers growth during periods of invention, while it enhances it in times of innovation.

\section{Conclusion}

Over the centuries, there were changes in the way elites were recruited. From the end of the nineteenth century, the ticket to set foot into the elite was to enter an elite university, and until World War II, access to these elite universities was largely restricted to the upper class. After World War II, entry to elite universities was achieved through meritocratic recruitment and was not dependent anymore upon wealth; the best were chosen.

The idea of meritocracy made inroads, and new blood entered elite universities in the US, Oxbridge in the UK, and the grandes écoles and the ENA in France. Consequently, the first postchange elite was recruited in a diverse way, by successful performance in exams. For the first generation after these changes in recruitment, elite universities were not only enabled to choose the best, but also provided an opportunity for some who did not belong to the elite milieu to enter the best schools.

In succeeding generations, however, exams have not permitted opportunity for all, as shown by our model. In the second post-change generation, the children of the elite enter the elite schools in greater proportions, due to a cultural bias. In other words, whenever a new system is introduced, the nascent class system is destroyed, yielding a fluid, mobile society. However, from the second post-change generation on, the children of the elite again have an advantage. Our model has shown that meritocratic exams lead to an auto-recruitment of elites, resulting in a stratification effect. Meritocratic choice is therefore not equivalent to equal opportunity, since success in exams is correlated with family wealth and education.

This stratification effect exists in France, but also in the US. Over time, recruitment either through SAT or concours leads to a stratification effect. We have shown that the stratification effect will be greater in France due to achievement and knowledge-based tests vs. the American SATs, and also due to the fact that in France, recruitment levels are narrower $\equiv$ owever, the two levels of recruitment that exist in France lead to an opposite effect. Indeed, as counter-intuitive as it appears, the double system of the baccalauréat and two years later (or more), the grandes écoles entry exams is actually a superior system of recruitment. Despite these differences, over the years, there has occurred some convergence in the way the Western world recruits and educates its elite; with the exception of Germany, the elites are recruited through elite schools and from elite families.

The second part of our paper has checked the effect of this type of recruitment on economic growth. We have shown that these systems work very well in times of minor changes in 
technology, and they do allow for economic growth. However, during times of major technological change, the system of elite recruitment can actually cause a slowdown in the adoption of new technologies. Presumably, the best situation would entail periodic changes in the types of exams, causing the circulation of the elite to widen. However, for the French system to accept recruitment to the grandes écoles by exams such as the SAT would surely demand another revolution!

In conclusion, this paper has shown that the stratification effect in the recruitment of elites is due to the entry exams to universities. The democratization of the universities has led to education of masses but not to a "democratization" of the elites. The policies, which were adopted after World War II to widen the recruitment of elites were at first a success, but over time there was a perverse stratification effect and the circulation of elites receded, with the specified consequences for the economy. 


\section{References}

Arrow, K., S. Bowles and S. Durlauf (eds). 2000. Meritocracy and Economic Inequality. Princeton: Princeton University Press.

Baverez, N. 1998. “Etrange capitalisme à la française.” Sociétal March: 30-31.

Blau, P.M. and O.D. Duncan. 1967. The American Occupational Structure. New York: Wiley.

Bouchard, T.J. and M. McCue. 1981. "Familial Studies of Intelligence." Science, 212:105559.

Brezis, E.S., P. Krugman and D. Tsiddon. 1993. "Leapfrogging in International Competition: A Theory of Cycles in National Technological Leadership." American Economic Review, pp.1211-1219.

Brezis, E.S. and F. Crouzet. 1999. "Elites Schools, Circulation of Elites and Economic Development: the ENA case" in Brezis, E.S. and P. Temin (eds). Elites, Minorities and Economic Growth. New York: Elsevier, North-Holland, pp.235-49.

Brezis, E.S. and F. Crouzet. 2004. "Changes in the Training of the Power Elites in Western Europe." Journal of European Economic History, 33(1): 33-58.

Brigham, C.C. 1923. A Study of American Intelligence. Princeton: Princeton University Press.

Cappon, Lester J. 1959. The Adams-Jefferson Letters: The complete correspondence between Thomas Jefferson and Abigail and John Adams. Chapell Hill: University of North Carolina Press.

Durlauf, S. 1999. "The Memberships Theory of Inequality: Ideas and Implications" in Brezis, E.S. and P. Temin (eds), Elites, Minorities and Economic Growth. New York: Elsevier, North-Holland, pp.161-78.

Gaillard, J-M. 1995. L'ENA, Miroir de L'Etat. Bruxelles: Complexe.

Galor, O. and D. Tsiddon. 1997. "Technological Progress, Mobility, and Growth." American Economic Review 87: 363-82.

Gardner, J. 1995. Excellence: Can we be Equal and Excellent Too? New York: Norton and Co.

Herrnstein, R.J. and C.A. Murray. 1994. The Bell Curve: Intelligence and Class Structure in American Life. New York: Free Press. 
Hoffmann, B. 1962. The Tyranny of Testing. New York: Crowell-Collier Press.

Jensen, A.R. 1989. “Raising IQ without raising Intelligence?” Developmental Review, 9: 23458.

Kaelble, H. 1979. "L'évolution du recrutement du patronat en Allemagne comparée à celle des Etats-Unis et de la Grande-Bretagne depuis la Révolution Industrielle" in Lévy-Leboyer, M. ed. Le patronat de la seconde industrialisation. Paris: Les éditions ouvrières.

Kingston, P.W. and L.S. Lewis. 1990. "Undergraduates at Elite institutions: The Best, the Brightest, and the Richest" in Kingston, P.W. and L.S. Lewis, eds., The High Status Track. Albany: State University of New York Press, pp.105-20.

Lemann, N. 1999. The Big Test. The Secret History of the American Meritocracy. New York: Farrar, Strauss, Giroux.

Lévy-Leboyer, M. ed. 1979. Le patronat de la seconde industrialisation. Paris: Les éditions ouvrières.

Miller, W. 1949. “American Historians and the Business Elite". Journal of Economic History, 9(2): 184-208.

Miller, W. 1950. "The Recruitment of the American Business Elite". Quarterly Journal of Economics, 64(2): 242-53.

Nairn, A. and R. Nader. 1980. The Reign of ETS: The Corporation that makes up Minds.

Neal, D.A. and W.A. Johnson. 1996. "The Role of Premarket Factors in Black-white Wage Differences.” Journal of Political Economy, 104:869-95.

Pareto, V. 1965. Les systèmes socialistes. Genève: Droz.

Pareto, V. 1935. The Mind and Society. New-York: Harcourt Brace.

Rubinstein, W.D. 1993. Capitalism, Culture and Decline in Britain, 1750-1990. London: Routledge.

Taussig, F.W. and C.S. Joslyn. 1932. American Business Leaders: A Study in Social Origins and Social Stratification. New-York: Macmillan.

Temin, P. 1999a. "The American Business Elite in Historical Perspective" in Brezis, E.S. and P. Temin (eds), Elites, Minorities and Economic Growth. New York: Elsevier, North-Holland, pp.19-40.

Temin, P. 1999b. "The Stability of the American Business Elite" Industrial and Corporate Change, June. 
Temin, P. 2002. "Teacher Quality and the Future of America", Eastern Economic Journal, 28: 285-300. 


\title{
CESifo Working Paper Series
}

\author{
(for full list see www.cesifo.de)
}

1297 David S. Evans and Michael Salinger, An Empirical Analysis of Bundling and Tying: Over-the-Counter Pain Relief and Cold Medicines, October 2004

1298 Gershon Ben-Shakhar, Gary Bornstein, Astrid Hopfensitz and Frans van Winden, Reciprocity and Emotions: Arousal, Self-Reports, and Expectations, October 2004

1299 B. Zorina Khan and Kenneth L. Sokoloff, Institutions and Technological Innovation During Early Economic Growth: Evidence from the Great Inventors of the United States, 1790 - 1930, October 2004

1300 Piero Gottardi and Roberto Serrano, Market Power and Information Revelation in Dynamic Trading, October 2004

1301 Alan V. Deardorff, Who Makes the Rules of Globalization?, October 2004

1302 Sheilagh Ogilvie, The Use and Abuse of Trust: Social Capital and its Deployment by Early Modern Guilds, October 2004

1303 Mario Jametti and Thomas von Ungern-Sternberg, Disaster Insurance or a Disastrous Insurance - Natural Disaster Insurance in France, October 2004

1304 Pieter A. Gautier and José Luis Moraga-González, Strategic Wage Setting and Coordination Frictions with Multiple Applications, October 2004

1305 Julia Darby, Anton Muscatelli and Graeme Roy, Fiscal Federalism, Fiscal Consolidations and Cuts in Central Government Grants: Evidence from an Event Study, October 2004

1306 Michael Waldman, Antitrust Perspectives for Durable-Goods Markets, October 2004

1307 Josef Honerkamp, Stefan Moog and Bernd Raffelhüschen, Earlier or Later: A General Equilibrium Analysis of Bringing Forward an Already Announced Tax Reform, October 2004

1308 M. Hashem Pesaran, A Pair-Wise Approach to Testing for Output and Growth Convergence, October 2004

1309 John Bishop and Ferran Mane, Educational Reform and Disadvantaged Students: Are They Better Off or Worse Off?, October 2004

1310 Alfredo Schclarek, Consumption and Keynesian Fiscal Policy, October 2004

1311 Wolfram F. Richter, Efficiency Effects of Tax Deductions for Work-Related Expenses, October 2004 
1312 Franco Mariuzzo, Patrick Paul Walsh and Ciara Whelan, EU Merger Control in Differentiated Product Industries, October 2004

1313 Kurt Schmidheiny, Income Segregation and Local Progressive Taxation: Empirical Evidence from Switzerland, October 2004

1314 David S. Evans, Andrei Hagiu and Richard Schmalensee, A Survey of the Economic Role of Software Platforms in Computer-Based Industries, October 2004

1315 Frank Riedel and Elmar Wolfstetter, Immediate Demand Reduction in Simultaneous Ascending Bid Auctions, October 2004

1316 Patricia Crifo and Jean-Louis Rullière, Incentives and Anonymity Principle: Crowding Out Toward Users, October 2004

1317 Attila Ambrus and Rossella Argenziano, Network Markets and Consumers Coordination, October 2004

1318 Margarita Katsimi and Thomas Moutos, Monopoly, Inequality and Redistribution Via the Public Provision of Private Goods, October 2004

1319 Jens Josephson and Karl Wärneryd, Long-Run Selection and the Work Ethic, October 2004

1320 Jan K. Brueckner and Oleg Smirnov, Workings of the Melting Pot: Social Networks and the Evolution of Population Attributes, October 2004

1321 Thomas Fuchs and Ludger Wößmann, Computers and Student Learning: Bivariate and Multivariate Evidence on the Availability and Use of Computers at Home and at School, November 2004

1322 Alberto Bisin, Piero Gottardi and Adriano A. Rampini, Managerial Hedging and Portfolio Monitoring, November 2004

1323 Cecilia García-Peñalosa and Jean-François Wen, Redistribution and Occupational Choice in a Schumpeterian Growth Model, November 2004

1324 William Martin and Robert Rowthorn, Will Stability Last?, November 2004

1325 Jianpei Li and Elmar Wolfstetter, Partnership Dissolution, Complementarity, and Investment Incentives, November 2004

1326 Hans Fehr, Sabine Jokisch and Laurence J. Kotlikoff, Fertility, Mortality, and the Developed World's Demographic Transition, November 2004

1327 Adam Elbourne and Jakob de Haan, Asymmetric Monetary Transmission in EMU: The Robustness of VAR Conclusions and Cecchetti's Legal Family Theory, November 2004

1328 Karel-Jan Alsem, Steven Brakman, Lex Hoogduin and Gerard Kuper, The Impact of Newspapers on Consumer Confidence: Does Spin Bias Exist?, November 2004 
1329 Chiona Balfoussia and Mike Wickens, Macroeconomic Sources of Risk in the Term Structure, November 2004

1330 Ludger Wößmann, The Effect Heterogeneity of Central Exams: Evidence from TIMSS, TIMSS-Repeat and PISA, November 2004

1331 M. Hashem Pesaran, Estimation and Inference in Large Heterogeneous Panels with a Multifactor Error Structure, November 2004

1332 Maarten C. W. Janssen, José Luis Moraga-González and Matthijs R. Wildenbeest, A Note on Costly Sequential Search and Oligopoly Pricing, November 2004

1333 Martin Peitz and Patrick Waelbroeck, An Economist's Guide to Digital Music, November 2004

1334 Biswa N. Bhattacharyay and Prabir De, Promotion of Trade, Investment and Infrastructure Development between China and India: The Case of Southwest China and East and Northeast India, November 2004

1335 Lutz Hendricks, Why Does Educational Attainment Differ Across U.S. States?, November 2004

1336 Jay Pil Choi, Antitrust Analysis of Tying Arrangements, November 2004

1337 Rafael Lalive, Jan C. van Ours and Josef Zweimueller, How Changes in Financial Incentives Affect the Duration of Unemployment, November 2004

1338 Robert Woods, Fiscal Stabilisation and EMU, November 2004

1339 Rainald Borck and Matthias Wrede, Political Economy of Commuting Subsidies, November 2004

1340 Marcel Gérard, Combining Dutch Presumptive Capital Income Tax and US Qualified Intermediaries to Set Forth a New System of International Savings Taxation, November 2004

1341 Bruno S. Frey, Simon Luechinger and Alois Stutzer, Calculating Tragedy: Assessing the Costs of Terrorism, November 2004

1342 Johannes Becker and Clemens Fuest, A Backward Looking Measure of the Effective Marginal Tax Burden on Investment, November 2004

1343 Heikki Kauppi, Erkki Koskela and Rune Stenbacka, Equilibrium Unemployment and Capital Intensity Under Product and Labor Market Imperfections, November 2004

1344 Helge Berger and Till Müller, How Should Large and Small Countries Be Represented in a Currency Union?, November 2004

1345 Bruno Jullien, Two-Sided Markets and Electronic Intermediaries, November 2004 
1346 Wolfgang Eggert and Martin Kolmar, Contests with Size Effects, December 2004

1347 Stefan Napel and Mika Widgrén, The Inter-Institutional Distribution of Power in EU Codecision, December 2004

1348 Yin-Wong Cheung and Ulf G. Erlandsson, Exchange Rates and Markov Switching Dynamics, December 2004

1349 Hartmut Egger and Peter Egger, Outsourcing and Trade in a Spatial World, December 2004

1350 Paul Belleflamme and Pierre M. Picard, Piracy and Competition, December 2004

1351 Jon Strand, Public-Good Valuation and Intrafamily Allocation, December 2004

1352 Michael Berlemann, Marcus Dittrich and Gunther Markwardt, The Value of NonBinding Announcements in Public Goods Experiments: Some Theory and Experimental Evidence, December 2004

1353 Camille Cornand and Frank Heinemann, Optimal Degree of Public Information Dissemination, December 2004

1354 Matteo Governatori and Sylvester Eijffinger, Fiscal and Monetary Interaction: The Role of Asymmetries of the Stability and Growth Pact in EMU, December 2004

1355 Fred Ramb and Alfons J. Weichenrieder, Taxes and the Financial Structure of German Inward FDI, December 2004

1356 José Luis Moraga-González and Jean-Marie Viaene, Dumping in Developing and Transition Economies, December 2004

1357 Peter Friedrich, Anita Kaltschütz and Chang Woon Nam, Significance and Determination of Fees for Municipal Finance, December 2004

1358 M. Hashem Pesaran and Paolo Zaffaroni, Model Averaging and Value-at-Risk Based Evaluation of Large Multi Asset Volatility Models for Risk Management, December 2004

1359 Fwu-Ranq Chang, Optimal Growth and Impatience: A Phase Diagram Analysis, December 2004

1360 Elise S. Brezis and François Crouzet, The Role of Higher Education Institutions: Recruitment of Elites and Economic Growth, December 2004 